\title{
PENGARUH TERAPI AKUPUNKTUR JIN'S 3 NEEDLE TERHADAP PENURUNAN SKALA NYERI PADA PASIEN NYERI LUTUT DI DUSUN SIDOREJO DESA NGARGOREJO KECAMATAN NGEMPLAK BOYOLALI
}

\author{
Joko Tri Haryanto, Yuwinda Ginung Pradina, Estuningsih \\ Kementerian Kesehatan Politeknik Kesehatan Surakarta Jurusan Akupunktur
}

\begin{abstract}
Acupuncture Jin's 3 Needle for knee pain. Knee pain is a disorder of the musculoskeletal system include the patella bone, knee joints, and soft tissue (blood vessels, nerves, ligaments, muscles, and tendons). Knee pain is a painful disease that is often complained of by parents, adults, and children. In general, knee pain can occur immediately after trauma and may be due to degenerative factors or conditions caused by osteoarthritis, rheumatoid arthritis, and gout. According to the World Health Organization (WHO) in 2008, it is known that knee pain suffered by 151 million people around the world who occupy the sixth position causes mild motion obstacles to heavy movement obstacles. Therefore knee pain needs to get special treatment to overcome the complaints of pain. One of the handling quite effective to lower the pain scale is to use acupuncture therapy. This research is research pre-experimental design One-Group Pretest-Posttest Design with a sample of 17 residents of the village Ngargorejo village of Sidorejo Subdistrict Ngemplak Boyolali which meet the criteria of inclusion. Statistical tests using univariate analysis and bivariate analysis. In bivariate analysis use the wilcoxon test. Research results acupuncture therapy Jin's 3 Needle affects the decrease of pain scale in knee pain patients with p-value statistic test result 0,000 ( $p<$ $0,05)$ where $H_{0}$ is rejected and $H_{a}$ accepted.
\end{abstract}

Key words: Acupuncture Jin's 3 Needle, Liangqiu (ST 34), Knee pain, Xiyan (extra), and Xuehai (SP 10).

Abstrak: Terapi Akupunktur Jin's 3 Needle untuk Nyeri Lutut. Nyeri lutut merupakan suatu gangguan sistem muskuloskeletal meliputi tulang patela, sendi lutut, dan jaringan lunak (pembuluh darah, saraf, ligamen, otot, dan tendon). Nyeri lutut merupakan penyakit nyeri yang sering dikeluhkan oleh orang tua, dewasa, maupun anak-anak. Secara umum, nyeri lutut dapat terjadi segera setelah mengalami trauma dan bisa karena faktor atau kondisi degeneratif yang disebabkan oleh osteoarthritis (radang sendi), rematoid arthritis, dan gout. Menurut World Health Organization (WHO) tahun 2008, diketahui bahwa nyeri lutut diderita 151 juta jiwa di seluruh dunia yang menempati posisi ke enam penyebab hambatan gerak ringan sampai hambatan gerak berat. Maka dari itu nyeri lutut perlu mendapatkan penanganan khusus untuk mengatasi keluhan nyerinya. Salah satu penanganan yang cukup efektif untuk menurunkan skala nyeri adalah dengan menggunakan terapi akupunktur. Penelitian ini merupakan penelitian pre-eksperimental dengan rancangan One-Group Pretest-Posttest Design dengan sampel 17 orang warga Dusun Sidorejo Desa Ngargorejo Kecamatan Ngemplak Boyolali yang memenuhi kriteria inklusi. Uji statistik menggunakan analisis univariat 
dan analisis bivariat. Pada analisis bivariat menggunakan uji wilcoxon. Hasil penelitian menunjukkan terapi akupunktur Jin's 3 Needle berpengaruh terhadap penurunan skala nyeri pada pasien nyeri lutut dengan hasil uji statistik nilai $\mathrm{p}$ value $0,000(\mathrm{p}<0,05)$ dimana $\mathrm{H}_{0}$ ditolak dan $\mathrm{H}_{\mathrm{a}}$ diterima.

Kata kunci: Akupunktur Jin's 3 Needle, Liangqiu (ST 34), Nyeri lutut, Xiyan (extra), dan Xuehai (SP 10).

\section{PENDAHULUAN}

Setiap orang menginginkan memiliki kapasitas fisik dan kemampuan fungsional yang baik untuk hidup produktif. Keinginan itu tidak mungkin dapat terwujud apabila seseorang mengalami nyeri pada bagian tubuhnya. Nyeri merupakan alasan yang paling umum orang mencari atau datang ke pelayanan kesehatan.The International Association for the Study of Pain(1979) mendefinisikan nyeri sebagai suatu rasa yang tidak menyenangkan dan merupakan pengalaman emosional yang berhubungan dengan kerusakan jaringan aktual maupun potensial dan terkadang nyeri digunakan untuk menyatakan adanya kerusakan jaringan (Parjoto, 2006).

Nyeri lutut merupakan suatu gangguan sistem muskuloskeletal meliputi tulang patela, sendi lutut, dan jaringan lunak (pembuluh darah, saraf, ligamen, otot, dan tendon). Nyeri lutut merupakan penyakit nyeri yang sering dikeluhkan oleh orang tua, dewasa, maupun anakanak. Secara umum, nyeri lutut dapat terjadi segera setelah mengalami trauma dan dapat karena faktor atau kondisi degeneratif yang disebabkan oleh osteoarthritis (radang sendi), rematoid arthritis, dan gout.

World Health Organization (WHO) tahun 2008 menyimpulkan bahwa nyeri lutut diderita 151 juta jiwa di seluruh dunia yang menempati posisi ke enam penyebab hambatan gerak ringan sampai hambatan gerak berat (Azlin dan Lyn, 2011). Pada tahun 1996 -1997, lebih dari 6 juta orang Amerika mencari perawatan medis untuk masalah lutut mereka, sekitar 5 juta orang mengunjungi ahli bedah tulang dan 1,4 juta orang datang ke rumah sakit. Data National Health and Nutrition Examination Survey (NHANES III) tahun 1988-1994 di Amerika Serikat, menunjukkan prevalensi nyeri lutut pada laki-laki adalah $18,1 \%$ dan pada perempuan 23,5\% (Mardhiyah dkk, 2011). Prevalensi nyeri lutut di Indonesia mencapai 5\% pada usia kurang dari 40 tahun, $30 \%$ pada usia 40 sampai 60 tahun, dan $65 \%$ pada usia lebih dari 65 tahun dan di RS Cipto Mangunkusumo, kasus nyeri lutut mencapai 56,7\% dari seluruh pasien yang berobat ke divisi Reumatologi Departemen Ilmu Penyakit Dalam. Insidensi pada usia kurang dari 20 tahun hanya sekitar $10 \%$ dan meningkat menjadi lebih dari $80 \%$ pada usia di atas 55 tahun.

Berdasarkan data diatas nyeri lutut perlu mendapatkan penanganan khusus untuk mengatasi keluhan nyeri, biasanya secara farmakologi pasien nyeri lutut diberikan obat-obatan seperti obat anti inflamasi non steroid (NSAID) dan obat analgesik atau obat penghilang rasa sakit. Sedangkan secara non farmakologi dapat diberikan terapi fisik, seperti fisioterapi dan terapi akupunktur.

Berbagai penelitian akupunktur untuk mengatasi nyeri lutut telah banyak 
dilakukan, seperti penelitian Itoh,et al.(2008) dengan judul "Trigger Point Acupuncture for Treatment of Knee Osteoarthritis" yang bertujuan untuk membandingkan efek dari metode terapi akupunktur trigger point dengan teknik akupunktur standar dan sham akupunktur terhadap penurunan skala nyeri lutut karena osteoarthritis. Hasilnya metode terapi akupunktur trigger point lebih efektif untuk menurunkan skala nyeri lutut dibandingkan dengan terapi akupunktur standar maupun sham akupunktur.

Pada penelitian ini, peneliti akan menggunakan metode akupunktur Jin's 3 Needle. Jin's 3 Needle merupakan metode terapi akupunktur dengan menggunakan 3 titik akupunktur pada suatu bagian tubuh. Pada penelitian ini titik yang digunakan adalah titik Xiyan (extra), Xuehai (SP 10) dan Liangqiu (ST 34). Peneliti tertarik menggunakan metode ini karena titik yang digunakan relatif sedikit dan lebih efisien untuk digunakan pada pasien nyeri lutut.

Penelitian ditujukan untuk mengetahui untuk mengetahui pengaruh terapi akupunktur Jin's 3 Needle terhadap penurunan skala nyeri pada pasien nyeri lutut.

\section{METODE PENELITIAN}

Penelitian ini dilaksanakan di Dusun Sidorejo Desa Ngargorejo Kecamatan Ngemplak Boyolali.

Penelitian ini merupakan penelitian pre-eksperimental design dengan rancangan One-GroupPretestPosttest Design. Dan uji analisis bivariat pada penelitian ini menggunakan uji Wilcoxon.

Populasi dalam penelitian ini adalah warga di Dusun Sidorejo Desa Ngargorejo Kecamatan Ngemplak Boyolali yang mengalami nyeri lutut dan dari hasil studi pendahuluan jumlah populasi dalam penelitian ini adalah 27 orang.

Namun yang bersedia menjadi responden penelitian dan masuk kriteria inklusi sebanyak 17 orang. Sehingga dapat disimpulkan jumlah sampel pada penelitian ini adalah 17 orang.

Variabel bebas yang digunakan dalam penelitian ini adalah pengaruh terapi akupunktur Jin's 3 Needle. Sedangkan variabel terikat pada penelitian ini adalah penurunan skala nyeri lutut.

\section{HASIL PENELITIAN \\ Analisis Univariat}

Analisis univariat pada penelitian ini memuat karakteristik responden berdasarkan usia, jenis kelamin, pekerjaan, dan skala nyeri sebelum dan setelah dilakukan terapi akupunktur.

\section{Tabel 1}

Distribusi Frekuensi Subyek Penelitian Berdasarkan Usia

\begin{tabular}{ccc}
\hline Usia & $\begin{array}{c}\text { Frekuensi } \\
(\mathrm{f})\end{array}$ & $\begin{array}{c}\text { Presentase } \\
(\%)\end{array}$ \\
\hline $35-47$ & 6 & 35,3 \\
$48-60$ & 11 & 64,7 \\
\hline Total & 17 & 100 \\
\hline
\end{tabular}

Tabel 2

Distribusi Subyek Penelitian

Berdasarkan Jenis Kelamin

\begin{tabular}{ccc}
\hline $\begin{array}{c}\text { Jenis } \\
\text { Kelamin }\end{array}$ & $\begin{array}{c}\text { Frekuensi } \\
\text { (f) }\end{array}$ & $\begin{array}{c}\text { Presentase } \\
(\%)\end{array}$ \\
\hline Laki-laki & 4 & 23,5 \\
Perempuan & 13 & 76,5 \\
\hline Jumlah & 17 & 100 \\
\hline
\end{tabular}


Tabel 3

Distribusi Subyek Penelitian Berdasarkan Pekerjaan

\begin{tabular}{ccc}
\hline Pekerjaan & $\begin{array}{c}\text { Frekuensi } \\
\text { (f) }\end{array}$ & $\begin{array}{c}\text { Presentase } \\
(\%)\end{array}$ \\
\hline IRT & 6 & 35,3 \\
Wiraswasta & 4 & 23,5 \\
Petani & 2 & 11,8 \\
Buruh Pabrik & 4 & 23,5 \\
Tambak & 1 & 5,9 \\
Waduk & & \\
\hline Total & 17 & 100 \\
\hline
\end{tabular}

\section{Tabel 4}

Penurunan Skala Nyeri Lutut Sebelum dan Setelah Terapi

\begin{tabular}{cccccc}
\hline \multirow{2}{*}{$\begin{array}{c}\text { Kate- } \\
\text { gori }\end{array}$} & Keterangan & \multicolumn{2}{c}{ Sebelum } & \multicolumn{2}{c}{ Setelah } \\
\cline { 3 - 6 } & $\mathrm{F}$ & $\%$ & $\mathrm{~F}$ & $\%$ \\
\hline 0 & tidak nyeri & 0 & 0 & 1 & 5,9 \\
$1-3$ & nyeri ringan & 0 & 0 & 11 & 64,7 \\
$4-6$ & nyeri sedang & 8 & 47,1 & 5 & 29,4 \\
$7-9$ & $\begin{array}{c}\text { nyeri berat } \\
\text { terkontrol } \\
\text { nyeri berat } \\
\text { tidak }\end{array}$ & 9 & 52,9 & 0 & 0 \\
10 & & 0 & 0 & 0 \\
& $\begin{array}{c}\text { terkontol } \\
\end{array}$ & & & &
\end{tabular}

$\begin{array}{lllll}\text { Total } & 17 & 100 & 17 & 100\end{array}$

\section{Analisis Bivariat}

\section{Uji Normalitas Data}

Sebelum dilakukan pengujian hipotesis, maka terlebih dahulu dilakukan uji normalitas data. Menurut Dahlan (2008) pada uji normalitas, karena jumlah sampel kecil $(\mathrm{n}<50)$ maka dianjurkan menggunakan Saphiro-wilk.

Dari pernyataan tersebut peneliti menggunakan Saphiro-wilk sebagai uji normalitas, karena jumlah responden kurang dari $50(\mathrm{n}=17)$. Hasil analisa statistik dapat dilihat pada tabel 5 .
Tabel 5

Uji Normalitas Data

\begin{tabular}{|c|c|}
\hline Karakteristik & $\begin{array}{l}\text { Saphiro-wilk } \\
\text { Sig. }\end{array}$ \\
\hline $\begin{array}{c}\text { Sebelum } \\
\text { Terapi }\end{array}$ & 0,000 \\
\hline $\begin{array}{c}\text { Setelah } \\
\text { Terapi }\end{array}$ & 0,000 \\
\hline $\begin{array}{l}\text { Dari d } \\
\text { disimpulkan b } \\
\text { dengan Saphi } \\
\text { sebelum terapi } \\
\text { adalah 0,000 } \\
\text { akupunktur Jin } \\
\text { Dari hasil te } \\
\text { bahwa data t }\end{array}$ & $\begin{array}{l}\text { tabel } 5 \text { di atas dapat } \\
\text { va hasil uji normalitas } \\
\text { wilk didapatkan hasil } \\
\text { upunktur Jin's } 3 \text { Needle } \\
\text { n hasil setelah terapi } \\
3 \text { Needle adalah } 0,000 \\
\text { ut dapat disimpulkan } \\
\text { but tidak berdistribusi } \\
\text { ilnya kurang dari } 0,05 \text {. }\end{array}$ \\
\hline
\end{tabular}

\section{Uji Hipotesis}

Berdasarkan hasil uji normalitas data penelitian pengaruh terapi akupunktur Jis's 3 Needle terhadap penurunan skala nyeri pada pasien nyeri lutut di Dusun Sidorejo Desa Ngargorejo Kecamatan Ngemplak Boyolali sebelum dilakukan dan setelah dilakukan terapi dengan Saphiro-wilk terlihat nilai sig. $0,000(\mathrm{p}<0,05)$, maka uji hipotesis dalam penelitian ini menggunakan uji Wilcoxon. Hasil pengukuran menggunakan uji Wilcoxon dapat dilihat pada tabel 6

Tabel 6

Analisis Wilcoxon

Hasil Skala Nyeri

Sebelum - Setelah

\begin{tabular}{cc}
\hline Z Hitung & $-3,787$ \\
\hline $\mathrm{p}$ Value & 0,000 \\
\hline Dengan uji & Wilcoxon didapatkan
\end{tabular}
nilai signifikansi ( $p$ Value) 0,000 dan nilai $\mathrm{Z}$ bernilai negatif $(-3,787)$ untuk penurunan skala nyeri lutut sehingga dapat disimpulkan bahwa terdapat 
penurunan skala nyeri lutut sebelum dan setelah dilakukan terapi akupunktur Jin's 3 Needle.

\section{PEMBAHASAN}

Pembahasan univariat berdasarkan usia pada tabel 1 didapatkan hasil bahwa distribusi frekuensi subyek penelitian berdasarkan usia adalah pada kelompok usia 48 - 60 tahun yaitu sebesar 11 orang $(64,7 \%)$ dan kelompok usia 35 - 47 tahun sebesar 6 orang $(35,3 \%)$ dan nilai maksimum berada pada usia 59 tahun sedangkan nilai minimum pada usia 36 tahun dengan hasil rata-rata usia 49,53.

Muttaqin (2012) menyebutkan salah satu faktor resiko yang dapat menyebabkan nyeri lutut adalah usia yang umumnya ditemukan pada usia lanjut (diatas 60 tahun), karena pada lansia telah terjadi perubahan-perubahan fisik, serta berkurangnya pembentukkan substansi dasar tulang rawan. Pada penelitian ini dihasilkan jumlah responden terbanyak yang mengalami nyeri lutut adalah pada kelompok usia 48 - 60 tahun.

Pembahasan univariat berdasarkan jenis kelamin pada tabel 2 didapatkan hasil bahwa distribusi frekuensi subyek penelitian berdasarkan jenis kelamin adalah pada jenis kelamin laki-laki ada 4 orang $(23,5 \%)$ dan jenis kelamin perempuan ada 13 orang (76,5\%), sehingga dapat disimpulkan hasil distribusi frekuensi subyek penelitian berdasarkan jenis kelamin terbanyak adalah jenis kelamin perempuan sebesar $76,5 \%$.

Hal tersebut juga diperjelas oleh Nadler, et al. (2013) bahwa sebagian besar jumlah penderita nyeri lutut lebih banyak terjadi pada wanita dikarenakan banyak terjadi perubahan fisiologi pada tubuh wanita dibanding.
Pembahasan univariat berdasarkan pekerjaan pada tabel 3 didapatkan hasil bahwa distribusi frekuensi subyek penelitian berdasarkan pekerjaan adalah pada pekerjaan IRT ada 6 orang $(35,3 \%)$, wiraswasta ada 4 orang $(23,5 \%)$, petani ada 2 orang $(11,8 \%)$, buruh pabrik ada 4 orang $(23,5 \%)$, dan tambak waduk ada 1 orang $(5,9 \%)$, sehingga hasil terbanyak distribusi frekuensi subyek penelitian berdasarkan pekerjaan adalah pada pekerjaan IRT (Ibu Rumah Tangga) sebesar 35,3\%.

Pembahasan univariat berdasarkan penurunan skala nyeri pada tabel 4 skala nyeri sebelum dilakukan terapi diketahui dari responden total berjumlah 17 orang dengan kategori skala nyeri sebelum dilakukan terapi akupunktur Jin's 3 Needle pertama, kategori skala nyeri lutut terbanyak adalah nyeri berat terkontrol dengan skala nyeri 7 - 9 diderita sebanyak 9 orang dengan presentase 52,9\% dan sebelum terapi dilakukan nilai maksimum skala nyeri adalah 8 sedangkan nilai minimum skala nyeri adalah 4 dengan rata-rata skala nyeri 6,35. Skala nyeri setelah dilakukan terapi akupunktur Jin's 3 Needle ke 12 diketahui dari responden total berjumlah 17 orang dengan kategori skala nyeri setelah dilakukan terapi, kategori skala nyeri lutut terbanyak adalah nyeri ringan dengan skala nyeri 1 - 3 diderita sebanyak 11 orang dengan presentase $64,7 \%$ dan setelah terapi dilakukan nilai maksimum skala nyeri adalah 5, sedangkan nilai minimum skala nyeri adalah 0 dengan rata-rata skala nyeri 2,53.

Sehingga dilihat dari tabel 4 terjadi penurunan skala nyeri sebelum dilakukan terapi dan setelah dilakukan terapi karena kategori nyeri berat terkontrol dengan skala nyeri $7-9$ yang awalnya diderita 
sebanyak 9 orang tetapi setelah terapi ke 12 kategori nyeri berat terkontrol 0 orang. Kategori nyeri sedang dengan skala nyeri $4-6$ yang awalnya diderita oleh 8 orang setelah terapi ke 12 yang menderita skala nyeri sedang ada 5 orang, kemudian setelah terapi ke 12 ada 11 orang yang tinggal mengalami nyeri ringan dengan skala nyeri $1-3$ dan ada 1 orang yang sudah sembuh tidak mengalami nyeri lagi. Kemudian dilihat dari rata-rata skala nyeri sebelum terapi dilakukan adalah 6,35 dan rata-rata skala nyeri setelah terapi dilakukan adalah 2,53 menunjukkan adanya penurunan skala nyeri lutut.

Pembahasan bivariat pada

penelitian ini menunjukkan hasil penelitian tentang pengaruh terapi akupunktur Jis's 3 Needle terhadap penurunan skala nyeri pada pasien nyeri lutut di Dusun Sidorejo Desa Ngargorejo Kecamatan Ngemplak Boyolali menggunakan uji wilcoxon didapatkan hasil nilai signifikansi p value $0,000(\mathrm{p}<$ $0,05)$ yang berarti terapi akupunktur Jin's 3 Needle berpengaruh terhadap penurunan skala nyeri pada pasien nyeri lutut.

Beberapa faktor yang yang mempengaruhi signifikansi hasil penelitian ini adalah karena responden belum masuk usia lanjut lebih dari 60 tahun dan kebanyakan bekerja sebagai ibu rumah tangga.

Penurunan skala nyeri lutut menggunakan terapi akupunktur Jin's 3 Needle dengan melakukan penusukan pada titik Xiyan (extra), Xuehai (SP 10) dan Liangqiu (ST 34) menimbulkan reaksi deqi (rasa baal, berat, kemeng) yang pada akhirnya akan merangsang pelepasan neurotransmitter penghambat nyeri melalui mekanisme kerja akupunktur analgesia. Rangsangan jarum akupunktur akan ditangkap oleh ujung bebas saraf sensorik C atau tipe I diteruskan ke medula spinalis di kornu posterior lamina II dan $\mathrm{V}$, dimana terjadi sinaps sebagai antero lateral tract (ALT) menuju hypothalamus pituitary complex.

Cabang kolateral segmental pendek ke sel $M$ (sel marginal) di tepi lamina II yang akan merangsang stalked cells di dalam lamina II melepaskan enkefalin, dinorfin yang menyebabkan gerbang untuk nyeri menutup, sehingga tidak memberi kesempatan rangsangan nyeri dari tempat lain untuk diteruskan ke otak. ALT naik dan memberi kolateral yang menuju ke mesensefalon dan komplek pituitari hipothalamus.

Dalam perjalanannya di level mesensofalon memberikan cabang ke sel PAG (yang akan melepas $\beta$ endorfin), sel nukleus rafe magnus (yang ada di ujung kaudal medula oblongata melepas serotonin) serta ke nukleus retikularis paragigantoselularis (yang akan melepas noradrenalin). Ketiga transmitter tersebut yang akan menghambat implus saraf yang membawa pesan nyeri yang berasal dari tempat lain.

Dalam perjalanan naik ke thalamus, masih ada lagi kolateral yang menuju ke komplek pituitari hipothalamus di nukleus arcuatus hipothalami (yang melepas $\beta$ endorfin) serta ke pituitari melepas $\beta$ endorfin yang akan masuk ke sirkulasi darah dan beredar keseluruh tubuh (Saputra, 2009).

$$
\text { Penelitian ini sejalan dengan }
$$
penelitian Sumanto(2013) yang menemukan bahwa terapi akupunktur pada titik Zusanli (ST36), Yinlingquan (SP9), Shenshu (BL23), dan Taixi (KI3) berpengaruh terhadap pengurangan intensitas sakit nyeri sendi lutut dengan nilai signifikan sebesar 0,000 dan penelitian Keristianto, et al.(2013) yang 
meneliti pada titik Dubi (ST35), titik Zusanli(ST36), titik Yanglingquan(GB34), dan titik Xiyan (Extra) dengan hasil tingkat kepercayaan $95 \%$. Sedangkan dalam penelitian yang penulis lakukan untuk mengurangi skala nyeri pada pasien nyeri lutut hanya menggunakan 3 titik saja yaitu titik Xiyan (extra), Xuehai (SP 10) dan Liangqiu (ST 34) dan pada penelitian ini penulis tidak menggunakan modalitas terapi lain.

\section{KESIMPULAN DAN SARAN}

Dari hasil penelitian dapat disimpulkan bahwa pada penelitian ini terdiri dari 17 responden yang sebelum dilakukan terapi kategori nyeri berat terkontrol diderita sebanyak 9 orang dan nyeri sedang sebanyak 8 orang.

Setelah terapi akupunktur terjadi penurunan skala nyeri lutut yang awalnya nyeri berat terkontrol ada 9 orang setelah diterapi nyeri berat terkontrol menjadi 0 orang, nyeri sedang yang awalnya 8 orang menjadi 5 orang, kemudian ada 11 orang mengalami nyeri ringan dan ada 1 orang yang sudah sembuh tidak mengalami nyeri lagi.

Terapi akupunktur Jin's 3 Needle berpengaruh terhadap penurunan skala nyeri pada pasien nyeri lutut dengan hasil uji statistik nilai $\mathrm{p}$ value $0,000(\mathrm{p}<0,05)$ dimana $\mathrm{H}_{0}$ ditolak dan $\mathrm{H}_{\mathrm{a}}$ diterima.

Saran yang dapat disampaikan dari hasil penelitian ini adalah pada penelitian selanjutnya diharapkan menggunakan studi perbandingan dengan kelompok kontrol dan untuk lebih meningkatkan homogenitas, sampel penelitian diperlukan kriteria inklusi yang lebih sempit.

\section{DAFTAR RUJUKAN}

Azlin, N. dan Lyn, K. S., 2011. Effects of Passive Joint Mobilization on Patients. Sains Malaysiana, 14611465.

Dahlan, S., 2008. Statistik Untuk Kedokteran dan Kesehatan. Jakarta: Salemba Medika.

Itoh, K., et al., 2008. Acupuncture in Medicine: Trigger Point Acupuncture for Treatment of Knee Osteoarthritis, 26 (1): 17-26.

Keristianto, G. D., et al., 2013. Pengaruh Terapi Akupunktur Terhadap Penurunan Nyeri Lutut Pada Pasien Dengan Osteoarthritis Di Praktik Perawat Mandiri Latu Usadha Abiansemal. Denpasar: Jurnal Ilmu Keperawatan Fakultas Kedokteran Universitas Udayana.

Mardhiyah, D., Sulistomo, A. B., dan Ratnawati, A., 2011. Hubungan Nyeri Lutut Akut dengan Lama Mengemudi dan Faktor-faktor Lain pada Pengemudi Taksi Lakilaki. Jakarta Indonesia Med Assoc, 61: 244.

Muttaqin, A., 2012. Buku Saku Gangguan Muskuloskeletal Aplikasi pada Praktik Klinik Keperawatan. Jakarta: EGC.

Nadler, et al. 2013. Osteoarthritis. Delisa's Physical Medicine \& Rehabilitation: Principles and Practice. Philadelphia: Lippincott Williams \& Wilkins.

Parjoto, S., 2006. Terapi Listrik Untuk Modulasi Nyeri. Semarang: Ikatan Fisioterapi Indonesia Cabang Semarang.

Rui, Jin. 2004. Jin's 3 Needles Technique. Shanghai: Shanghai Scientif.

Saputra, K. dan Sudirman, S., 2009. Akupunktur Untuk Nyeri dengan 
pendekatan neurosain. Jakarta: Sagung Seto.

Sumanto, 2013. Pengaruh Titik Zusanli (ST36), Yinlingquan (SP9), Shenshu (BL23), dan Taixi (KI3)

Terhadap Pengurangan Intensitas
Sakit Nyeri Sendi Lutut (Sinrom Bi) Di Klinik Akupunktur RSO Prof DR. Soeharso Surakarta. Jurnal Terpadu Ilmu Kesehatan 2 (2): 41-155. 